\title{
PENERAPAN PENDEKATAN PEMECAHAN MASALAH MELALUI SOAL CERITA PECAHAN UNTUK MENINGKATKAN HASIL BELAJAR SISWA KELAS IV SDN CIHERANG KECAMATAN PAMULIHAN KABUPATEN SUMEDANG
}

\author{
Oleh: Aep Suryana \\ Dosen Program Studi PGSD Universitas Majalengka
}

\begin{abstract}
ABSTRAK
Berdasarkan data awal di kelas IV SDN Ciherang,pada umumnya siswa kesulitan menyelasaikan soal cerita pecahan. Proses belajar-mengajar yang dilakukan guru belum mencerminkan pembelajaran yang berorientasi pada keberhasilan proses pembelajaran. Dari permasalahan tersebut, maka diterapkan pendekatan pemecahan masalah dengan pola: memahami masalah yang ada dalam soal cerita, merencanakan penyelesaian dalam soal cerita, menyelesaikan masalah sesuai dengan rencana, dan melakukan pengecekan kembali terhadap semua langkah yang dikerjakan dalam soal cerita. Penelitian ini menggunakan metode PTK dengan desain penelitian mengacu ke Kemmis dan Taggart yang terdiri dari empat komponen, yaitu: perencanaan, tindakan, observasi dan refleksi. Instrumen yang digunakan terdiri dari lembar observasi kinerja guru dan aktivitas siswa, lembar wawancara, catatan lapangan dan tes yang diolah dengan menggunakan validasi data triangulasi, member cek, audit trail dan expertopinion. Penerapan pendekatan pemecahan masalah melalui soal cerita dapat meningkatnya hasil belajar siswa dengan rata-rata hasil tes individu dari data awal sebesar 56, siklus I sebesar 66, siklus II sebesar 73, dan siklus III sebesar 89.
\end{abstract}

Kata Kunci: pendekatan pemecahan masalah, soal cerita pecahan, hasil belajar

\section{Pendahuluan}

Matematika merupakan salah satu ilmu dasar yang dewasa ini telah berkembang cukup pesat, baik secara materi maupun kegunaannya.Oleh sebab itulah maka konsep-konsep dasar matematika harus dikuasai para siswa sejak dini yang pada akhirnya dapat terampil dan diterapkan dalam kehidupan sehari-hari.Mata pelajaran matematika perlu diberikan kepada semua siswa mulai dari SD untuk membekali para siswa memiliki kemampuan berpikir logis, analitis sistematis, kritis dan kreatif, serta kemampuan bekerjasama.Kompetensi tersebut diperlukan agar para siswa dapat memiliki kemampuan memperoleh, mengelola, dan memanfaatkan informasi untuk bertahan hidup pada keadaan yang selalu berubah, tidak pasti dan kompetitif.
Proses pembelajaran matematika menitikberatkan pada kegiatan siswa dalam bentuk penyelidikan dan penemuan, penalaran dan komunikasiserta pemecahan masalah. Melalui proses pembelajaran tersebut maka siswa SD dapat memiliki kompetensi dasar matematika sesuai dengan tuntutan kurikulum dan tuntutan zaman.

Begitu pentingnya konsep dasar matematika diajarkan di SD yang mempunyai banyak kegunaan, maka kegunaan tersebut dianggap bermanfaat apabila para siswa telah memiliki sejumlah kemampuan konsep dasar matematika yang salah satunya adalah memahami pecahan.Sehingga pengenalan pembelajaran pecahan mulai diajarkan di kelas III semester 2. Begitu juga di kelas IV, terdapat Kompetensi Dasar bahwa 
siswa harus dapat "Menyelesaikan masalah yang berkaitan dengan pecahan" (Depdiknas, 2006: 31).

Mengingat pentingnya pembelajaran soal cerita pecahan diajarkan di SD, maka peneliti mengadakan tes awal dengan memberikan soal sebanyak 2 soal cerita, maka diperoleh data dari jumlah seluruhnya 30 siswa hanya 10 orang atau $33 \%$ yang telah mencapai $\mathrm{KKM}$ dan 20 orang atau $767 \%$ belum, dengan rata-rata kelas baru mencapai 56.

Berdasarkan permasalahan tersebut di atas, maka dikembangkan salah satu pendekatan pembelajaran yaitu pendekatan pemecahan masalah. Pemecahan masalahmerupakan suatu proses yang terdiri dari beberapa langkah yang saling berkaitan. Karena menurut Gagne (Roni, 2004: 15), 'Pemecahan masalah adalah suatu proses agar siswa menemukan panduan dari aturan yang sebelumnya sudah dipelajari, untuk diterapkan dalam pemecahan masalah'

\section{Rumusan Masalah}

Berdasarkan masalah, maka rumusan masalah sebagai berikut:

1. Bagaimanakah perencanaan penerapan pendekatan pemecahan masalah melalui soal cerita untuk meningkatkan hasil belajar siswa kelas IV SDN Ciherang pada pembelajaran pecahan?

2. Bagaimanakah pelaksanaan penerapan pendekatan pemecahan masalah melalui soal cerita untuk meningkatkan hasil belajar siswa kelas IV SDN Ciherang pada pembelajaran pecahan?

3. Bagaimanakah peningkatan hasil belajar siswa terhadap soal cerita dengan penerapan pendekatan pemecahan masalah di kelas IV SDN Ciherang pada pembelajaran pecahan?

\section{Tujuan Penelitian} berikut:
1. Mengetahui perencanaan penerapan pendekatan pemecahan masalah melalui soal cerita untuk meningkatkan hasil belajar siswa kelas IV SDN Ciherang pada pembelajaran pecahan.

2. Mengetahui pelaksanaan penerapan pendekatan pemecahan masalah melalui soal cerita untuk meningkatkan hasil belajar siswa kelas IV SDN Ciherang pada pembelajaran pecahan.

3. Mengetahui peningkatan hasil belajar siswa terhadap soal cerita dengan penerapan pendekatan pemecahan masalah di kelas IV SDN Ciherang pada pembelajaran pecahan.

\section{Kajian Pustaka}

Pembelajaran soal cerita di SD tidak asing lagi dikalangan guru dan siswa. Akan tetapi dalam KTSP soal cerita identik namanya menjadi "pemecahan masalah". Hal ini didasarkan pada salah satu tujuan mata pelajaran matematika yang terdapat dalam KTSP 2006, agar siswa memiliki kemampuan: "Memecahkan masalah yang meliputi kemampuan memahami masalah, merancang model matematika, menyelesaikan model dan menafsirkan solusi yang diperoleh" (Depdiknas, 2006: 13).

Hakikat soal cerita mempunyai dampak yang besar dalam mengembangkan kosep dan keterampilan pemecahan masalah.Apabila siswa bekerja dalam soal cerita, maka siswa tersebut sedang bertugas untuk mencapai tujuan mengerjakan pemecahan masalah.

Menurut Hudojo (Aisyah 2007:3) bahwa: "Pemecahan masalah pada dasarnya adalah proses yang ditempuh oleh seseorang untuk menyelesaikan masalah yang dihadapinya sampai masalah itu tidak lagi menjadi masalah baginya." 


\begin{abstract}
Menurut Aisyah (2007:5) pemecahan masalah mempunyai karakteristik, yakni:

a. Memiliki lebih dari satu cara penyelesaian.

b. Memiliki lebih dari satu jawaban.

c. Melibatkan logika, penalaran, dan uji coba.

d. Sesuai dengan situasi nyata dan minat siswa.

Menurut Maulana (2006) ada jenisjenis pendekatan pemecahan masalah antara lain:
\end{abstract}

a. Masalah translasi, merupakan masalah kehidupan sehari-hari yang untuk menyelesaikan perlu translasi dari bentuk verbal kepada model matematika.

b. Masalah aplikasi, ketika menghadapi masalah aplikasi, kepadanya diberikan kesempatan seluas-luasnya untuk mencari solusi dengan menggunakan bermacam-macam keterampilan dan prosedur matematik.

c. Masalah proses, masalah proses menuntut kita untuk menyusun langkah-langkah, menyusun pola, dan melakukan pendekatan khusus dalam menyelesaikan masalah.

d. Masalah teka-teki, bertujuan untuk mengasah otak, tetapi juga untuk rekreasi, kesenangan, serta dapat dijadikan sebagai alat yang bermanfaat untuk mencapai tujuan afektif dalam pembelajaran matematika.

Suatu model yang dijadikan dasar untuk proses pemecahan masalah tersebut adalah model empat-tahap yang diusulkan oleh Polya(Suherman, 2001:84), yaitu:

a. Memahami masalah

b. Membuat rencana untuk menyelesaikannya

c. Melaksanakan rencana yang dibuat pada langkah kedua

d. Memeriksa ulang jawaban yang diperoleh.

Secara garis besar langkah-langkah pendekatan pemecahan masalah mengacu kepada model empattahap pemecahan masalah yang diusulkan oleh Polya (Aisyah, 2007) adalah sebagai berikut.

1) Memahami masalah Aisyah (2007:20) berpendapat bahwa dalam memahami masalah ajukan pertanyaan-pertanyaan berikut.

a) Apakah yang diketahui dari soal?

b) Apakah yang ditanyakan soal?

c) Apakah saja informasi yang diperlukan?

d) Bagaimana akan menyelesaikan soal?

2) Membuat rencana untuk menyelesaikan masalah

Pendekatan pemecahan masalah tidak akan berhasil tanpa perencanaan yang baik. Dalam perencanaan pemecahan masalah, siswa diarahkan untuk dapat mengidentifikasi pendekatan pemecahan masalah yang sesuai untuk menyelesaikan masalah. Dalam mengidentifikasi pendekatan pemecahan masalahini, hal yang paling penting untuk diperhatikan adalah apakah pendekatan tersebut berkaitan dengan permasalahan yang akan dipecahkan.

3) Melaksanakan penyelesaian soal Jika siswa telah memahami permasalahan dengan baik dan sudah menentukan pendekatan pemecahannya, langkah selanjutnya adalah melaksanakan penyelesaian soal sesuai dengan yang telah direncanakan. Kemampuan siswa memahami substansi materi dan keterampilan siswa melakukan perhitungan-perhitungan matematika akan sangat membantu siswa untuk melaksanakan tahap ini.

4) Memeriksa ulang jawaban yang diperoleh

Langkah memeriksa ulang jawaban yang diperoleh merupakan langkah terakhir dari pendekatan pemecahan 
masalah matematika.Langkah ini penting dilakukan untuk mengecek apakah hasil yang diperoleh sudah sesuai dengan ketentuan dan tidak terjadi kontradiksi dengan yang ditanya.

\section{Prosedur}

Prosedur penelitian ini menggunakan rancangan PTK. Hal ini didasarkan pada Kasbolah (1999: 22), bahwa salah satu karakteristik PTK berangkat dari permasalahan praktik faktual.Permasalahan faktual adalah permasalahan yang timbul dalam kegiatan pembelajaran sehari-hari yang dihadapi oleh guru.Rancangan PTK yang digunakan adalah model spiralyang dikembangkan oleh Kemmis dan Mc Taggart (Aqib, 2006: 31) yang terdiri dari empat komponen, yaitu: perencanaan (planning), tindakan (acting), observasi (observing) dan refleksi (reflecting). Adapun alat pengumpul data yang digunakan adalah lembar observasi, lembar wawancara, catatan lapangan, LKS, dan tes hasil belajar.

\section{Hasil}

Temua-temuan selama 3 siklus adalah sebagai berikut.

1. Siklus I

a. Perencanaan pembelajaran mencapai kategori cukup.

b. Kurang optimalnya guru dalam mengawasi kegiatan kelompok, membimbing kelompok dalam melaksanakan tahapan pemecahan masalah, memicu keterlibatan siswa, dan berkeliling kesetiap kelompok.

2. Siklus II

a. Perencanaanpembelajaran mencapai kategori baik.

b. Guru kurang memberikan memotivasi siswa dan kurang mengembangkan kemampuan bernalar.

3. Siklus III
a. Perencanaan pembelajaran mencapai kategori sangat baik.
b. Guru kurang peka terhadap kesalahan siswa.

Adapun hasil peningkatan dapat dilihat dalam diagram-diagram di bawah ini.

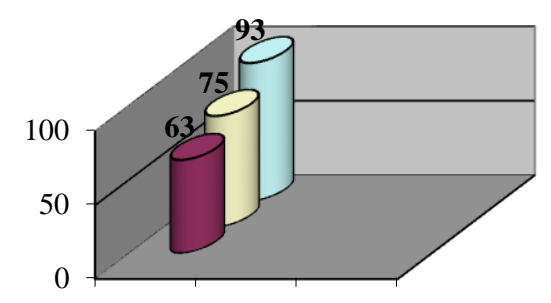

Diagram 1

Aktivitas Siswa

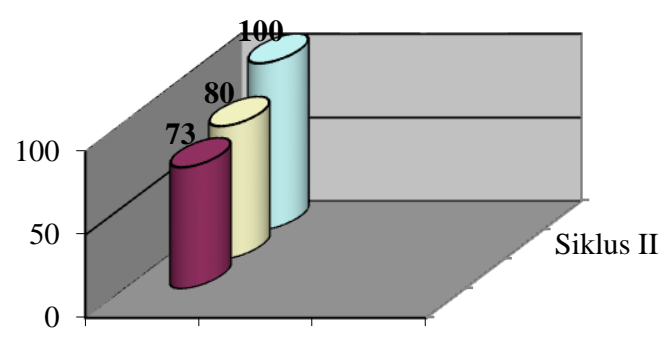

Diagram 2

Perencanaan Pembelajaran Soal Cerita
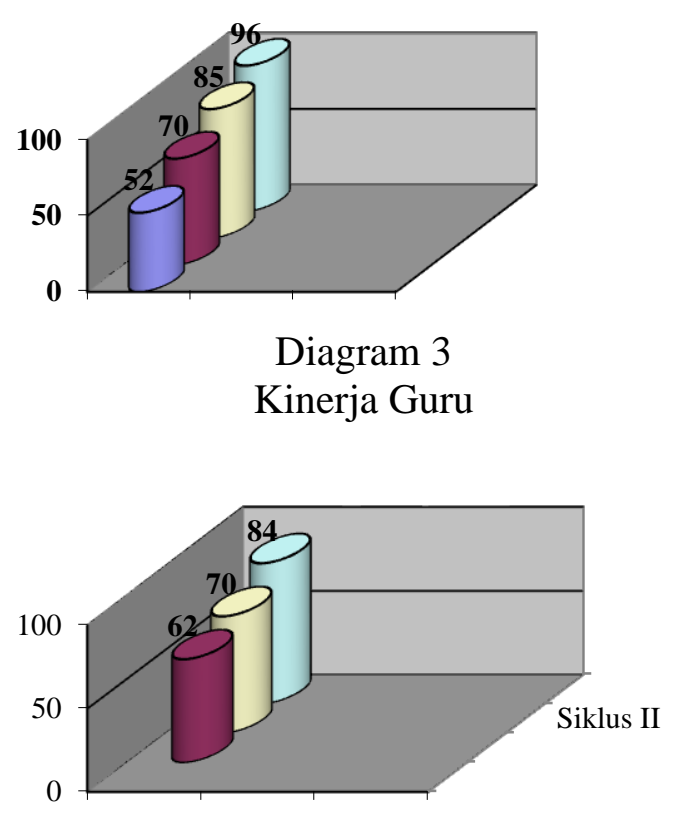

Diagram 4

Penilaian Proses 


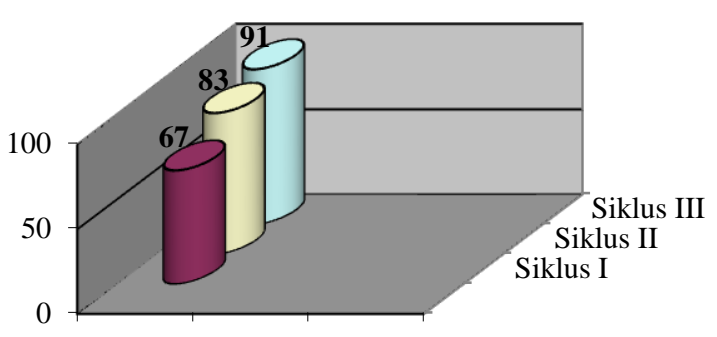

Diagram 5

Peningkatan Hasil Kelompok

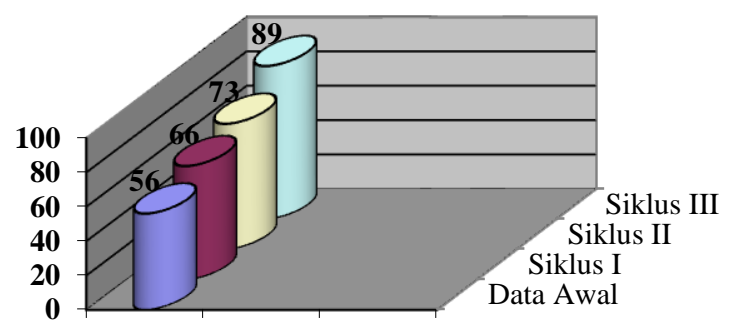

Diagram 6

Peningkatan Hasil Individu

Berdasarkan diagram, maka penerapan pendekatan pemecahan masalah dapat meningkatkan aktivitas siswa dan kinerja guru, baik secara proses maupun hasil dalam materi soal cerita pecahan di kelas IV SDN Ciherang.

\section{Kesimpulan}

1. Perencanaan:

a. Mempersiapkan RPP.

b. Mempersiapkan lembar soal.

c. Mempersiapkan pengelolaan kelas.

d. Menyiapkan format kinerja guru dan aktivitas siswa.

e. Instrumen pengumpul data.

f. Menyiapkan hasil pencapaian.

g. Menyiapkan aspek-aspek penilaian.

2. Pelaksanaan: a. Aktivitas siswa:

1) Aspek kerjasama rata-rata $92 \%$.

2) Aspek keaktifan rata-rata $94 \%$.

3) Aspek tanggung jawab, ratarata $93 \%$.

4) Memahami masalah.

5) Merencanakan penyelesaian masalah.

6) Pelaksanaan rencana penyelesaian sesuai dengan rencana.

7) Mengecek jawabandengan masalah yang ditanyakan.

b. Kinerja guru:

Mengkondisikan siswa kearah pembelajaran yang kondusif, menjelaskan tujuan yang dicapai, membangkitkan motivasi, memberikan pertanyaan yang menarik perhatian siswa, menciptakan kerjasama siswa, menjelaskan yang mudah dipahami, menjelaskan dengan menarik dan membangkitkan semangat siswa, memberikan kesempatan kepada siswa untuk berdiskusi, memberikan contoh yang dimengerti oleh siswa, memberikan kesempatan kepada siswa mengeluarkan pendapat,memeriksa pekerjaan siswa,memberikan evaluasi, memberikan balikan terhadap pekerjaan siswa, memberikan tindak lanjut,dan menutup pelajaran.

3. Hasil:

a. Aktivitas siswa siklus I sebesar $63 \%$, siklus II sebesar $75 \%$, dan siklus III sebesar 93\%.

b. Penilaian proses siswa siklus I sebesar 62\%, siklus II sebesar $70 \%$, dan siklus III sebesar $84 \%$.

c. Perencanaan pembelajaran siklus I sebesar 73\%, siklus II sebesar $80 \%$, dan siklus III sebesar $100 \%$.

d. Peningkatan kinerja guru dari data awal sebesar 52\%, siklus I sebesar 
$70 \%$, siklus II sebesar $85 \%$, dan siklus III sebesar $96 \%$.

e. Rata-rata hasil kelompok siklus I sebesar 67, siklus II sebesar 83, dan siklus III sebesar 91.

f. Rata-rata hasil individu mulai data awal 56, siklus I sebesar 66, siklus II sebesar 73, dan siklus III sebesar 89.

g. KKM data awal 33\%, siklus I sebesar 67\%, siklus II sebesar $90 \%$, dan siklus III sebesar $100 \%$.

\section{Daftar Pustaka}

Aisyah. (2007). Pendidikan Matematika di $S D$. Jakarta: Depdiknas.

Depdikbud.(1996). Strategi Pembelajaran Matematika. Jakarta: Depdikbud.

Depdiknas.(2003). Bimbingan dan Penyuluhan. Jakarta: Depdiknas.

Depdiknas.(2006). Kurikulum Tingkat Satuan Pendidikan. Jakarta: Depdiknas.

Depdiknas.(2011). Pembelajaran Matematika di SD untuk Program BERMUTU. Jakarta: Depdiknas.

Gie (1999) Filsafat Matematika. Yogyakarta: Pusat Belajar Ilmu Berguna.

Hawa, S. (2007).Pendidikan Matematika di SD. Jakarta: Depdiknas.

Heruman. (2007). Model Pembelajaran Matematika di SD. Bandung: Rosdakarya.

Hollands, R. (1995) Kamus Matematika. Jakarta: Erlanga.

Hudoyo. (1995) Kamus Matematika. Jakarta: Erlanga.
Kasbolah, K. (1999). Penelitian Tindakan Kelas. Jakarta: Depdikbud.

Karim.(1997). Pendidikan Matematika. Jakarta: Depdikbud.

Karso, (2005).Pendidikan Matematika I. Jakarta: Pusat Pendidikan UT.

Maulana.(2006). Konsep Dasar Matematika. Sumedang: UPI.

MKPBM.(2001).Strategi Pembelajaran Matematika Kontemporer. Bandung: JICA-UPI.

Moleong.L.J. (2004). Metodologi Penelitian Kualitatif. Bandung: Rosdakarya.

Panen, P., dkk. (2003). Belajar dan Pembelajaran 1.Jakarta: UT.

Pitajeng.(2006). Pembelajaran Matematika yang Menyenangkan. Jakarta: Depdiknas.

Purwoko.(2007). Pendidikan Matematika di SD Unit 3. Jakarta: Depdiknas

Raharjo, M. (2009). Pembelajaran Soal Cerita di SD. Yogyakarta: P4TK Matematika.

Roni.(2004). Kemampuan Memecahkan Masalah dalam Pembelajaran Pendidikan Dasar. Bandung: Jurnal Pendidikan Dasar UPI.

Rosida. (2004). Belajar Matematika Untuk Kelas IV. Bandung: PT SPK.

Ruseffendi.(1992), Pendidikan Matematika 3. Jakarta: Universitas Terbuka.

Sanjaya, W. (2006).Strategi Pembelajaran Berorientasi Standar Proses 
Pendidikan. Jakarta: Kencana Wiriaatmadja, R. (2005).Metode Predana Media Group.

Simanullang.(2009). Pemecahan Masalah Matematika. Jakarta: Depdiknas. Penelitian Tindakan Kelasuntuk Meningkatkan Kinerja Guru dan Dosen.Bandung: UPI dan Rosdakarya.

Soedjadi, (1994).Kiat Pendidikan Matematika di Indonesia. Jakarta: Dikti

Somakim. (2006). Pembelajaran Matematika di SD. Jakarta: Depdiknas.

Subarinah, (2006).Inovasi Pembelajaran Matematika SD. Jakarta: Depdiknas.

Suherman, ddk.(2001). Strategi Pembelajaran Matematika Kontemporer. Bandung: UPI.

Sutawidjaja, dkk.(1993). Pendidikan Matematika 3. Jakarta: Depdikbud.

Wibawa, B. (2003). Penelitian Tindakan Kelas. Jakarta: Depdiknas. 